\title{
PENGEMBANGAN BAHAN AJAR BIPA DARING TINGKAT PEMULA RENDAH
}

Online Teaching Materials Development of Indonesian as a Foreign Language for Beginner Low Level Learners

\author{
Ahmad Rofi'uddin ${ }^{a}$, Gatut Susanto ${ }^{b}$, Didin Widyartonoc, Sultan ${ }^{\text {d, }}$ \\ Helmi Muzaki ${ }^{\mathrm{e}}$, Pensri Panich ${ }^{\mathrm{f}}$ \\ a,b,c,e Universitas Negeri Malang \\ ${ }^{\mathrm{d} U n i v e r s i t a s}$ Negeri Makasar

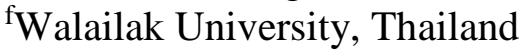 \\ rofiudin@um.ac.id
}

Naskah Diterima Tanggal 12 April 2020-Direvisi Akhir Tanggal 13 Mei 2021—Disetujui Tanggal 21 Juni 2021 doi: https://doi.org/10.26499/rnh.v10i1.3376

\begin{abstract}
Abstrak
Penelitian ini bertujuan untuk menghasilkan bahan ajar Bahasa Indonesia bagi Penutur Asing (BIPA) daring yang memiliki kelayakan untuk digunakan bagi pebelajar tingkat pemula rendah. Penelitian ini dilakukan di Malang pada tahun 2020. Prosedur yang digunakan adalah model (Gall et al., 2007). Karakteristik bahan ajar yang dihasilkan terdiri atas tiga belas unit pelajaran yang digunakan untuk pembelajaran BIPA secara daring. Tiap unit pelajaran dikembangkan bertumpu pada topik aktual sesuai dengan kebutuhan pebelajar tingkat pemula rendah. Topik-topik aktual tersebut antara lain tentang perkenalan, kampus, rumah, kantor, kantin, taman, dan pasar. Ragam bahasa Indonesia yang digunakan dalam bahan ajar ini ragam komunikatif. Selain itu, bahan ajar ini difasilitasi bahasa bantu bahasa Inggris. Berdasarkan uji pakai terhadap aspek isi, bahasa, dan struktur penyajian dapat disimpulkan bahwa bahan ajar BIPA daring untuk pebelajar tingkat pemula rendah daring ini memiliki kelayakan tinggi.
\end{abstract}

Kata-kata kunci: pengembangan, bahan ajar, BIPA daring, pemula rendah

\begin{abstract}
The aim of this study is to develop Indonesian language teaching online materials as a Foreign Language (BIPA) which are suitable for beginner low level learners. This research is conducted in Malang in 2020. The procedure in this study uses the (Gall et al., 2007). The characteristics of the product consist of thirteen lessons that are used for online BIPA learning. Each lesson is developed based on actual topics according to beginner low level learner needs. The actual topics cover introduction, campus, home, office, canteen, park, and market. The variety of Indonesian uses in this teaching material is communicative variety. In addition, this teaching material is equipped with English as an complementary language. Based on the use test on the aspects of content, language, and presentation order, it can be concluded that online BIPA teaching material for beginner low-level learners has high feasibility.
\end{abstract}

Keywords: development, teaching materials, online BIPA, low beginner

How to Cite: Rofi'uddin, Ahmad, dkk. (2021). Pengembangan Bahan Ajar BIPA Daring Tingkat Pemula Rendah. Ranah: Jurnal Kajian Bahasa. 10(1). 153-169. doi: https://doi.org/10.26499/rnh.v10i1.3376 


\section{PENDAHULUAN}

Penyelenggaraan pendidikan di seluruh dunia termasuk di Indonesia pada tahun 2020 mengalami perubahan drastis. Hal ini terjadi akibat wabah COVID-19 yang terjadi pada awal tahun 2020. Pelaksanaan pembelajaran yang biasanya dilaksanakan secara tatap muka secara tiba-tiba berubah menjadi kelas daring. Hal ini terjadi akibat penerapan protokol kesehatan yang membatasi pergerakan manusia untuk mencegah penyebaran virus COVID-19. Di Perguruan Tinggi, perubahan pembelajaran tatap muka menjadi pembelajaran daring ini dirasakan oleh dosen dan mahasiswa. Mereka melakukan kegiatan akademis pembelajarannya tidak lagi di kampus, tetapi dosen mengajar dari rumah dan mahasiswa belajar di rumah. Situasi ini dilaporkan oleh Corbera et al (2020) yang menyatakan bahwa COVID-19 telah memaksa akademisi bekerja di rumah. Dalam hal ini para akademisi perlu meningkatkan pengajaran daring dengan menguasai teknologi serta moda virtual yang bisa digunakan dalam pembelajaran daring.

Perubahan tiba-tiba ini juga terjadi pada pembelajaran Bahasa Indonesia bagi Penutur Asing (BIPA). Mahasiswa internasional yang belajar BIPA tidak diizinkan datang di Indonesia, mereka harus menghadapi pembelajaran BIPA secara daring di negara mereka. Pembelajaran BIPA yang biasanya dihadiri oleh dosen dan mahasiswa di suatu tempat yang sama, akibat pembatasan pergerakan orang yang disebabkan oleh pandemi COVID-19, mereka terpaksa melaksanakan pembelajaran BIPA secara daring di wilayah geografis yang berbeda (Moorhouse, 2020; Morgan, 2020; Murphy, 2020; Susanto et al., 2020). Situasi ini menuntut penyesuaian dalam banyak hal, seperti penyiapan perangkat pembelajaran, penguasaan teknologi pembelajaran, dan pengembangan bahan ajar. Penyiapan perangkat pembelajaran berupa jaringan internet, penguasaan teknologi pembelajaran berupa pengaplikasian modamoda pembelajaran virtual seperti Zoom, Google Meet, dan lain-lain. Terkait dengan pengembangan bahan ajar, perlu disiapkan bahan ajar BIPA yang sesuai dengan karakteristik pembelajaran daring dan tingkat kemahiran pebelajarnya.

Penelitian pengembangan bahan ajar BIPA telah dilakukan oleh para peneliti terdahulu. Beberapa peneliti mengembangkan bahan ajar BIPA secara diskrit. Misalnya, bahan ajar BIPA untuk keterampilan menyimak berbasis multimedia dikembangkan oleh Astuti \& Bewe (2020). Bahan ajar BIPA untuk keterampilan berbicara dikembangkan oleh (Hermanto, 2019; Pranandari, 2013; Nurlina, 2017; Ramadhani et al., 2016 \& Susetyo, 2017). Sebagian dari mereka mengembangkan bahan ajar BIPA untuk keterampilan berbicara tingkat pemula rendah dan sebagian lagi menghasilkan bahan ajar berbicara untuk pemula tinggi. Bahan ajar BIPA untuk keterampilan membaca dikembangkan oleh (Fariqoh, 2016) yang mengembangkan bahan ajar membaca untuk pembelajar tingkat pemula. Sementara itu, (Nuraeni, 2016) dan (Suprihatin, 2015) mengembangkan bahan ajar membaca untuk tingkat madya. Penelitian pengembangan bahan ajar BIPA untuk keterampilan menulis dilakukan oleh Nurlina \& Israhayu, (2014) yang mengembangkan bahan ajar untuk meningkatkan kemampuan menulis pebelajar Thailand.

Pengembangan bahan ajar BIPA secara integratif antara lain dilakukan oleh Fatahillah, (2020), Sari \& Cahyani, (2020), Tanwin \& Rosliani, (2020), serta Utami \& Rahmawati, (2020) yang mengembangkan bahan ajar BIPA untuk tingkat pemula. Bahan ajar BIPA tingkat menengah dikembangkan oleh Arumdyahsari et al (2017). Sementara itu, (Sriwulandari \& Ramadhani, 2018) mengembangkan bahan ajar BIPA untuk program Darmasiswa. Pengembangan bahan ajar lain dilakukan oleh (Yurensi et al., 2018) yang mengembangkan bahan ajar kosakata untuk BIPA anak usia dini dengan pendekatan integratif.

Pengembangan bahan ajar BIPA yang paling banyak dilakukan oleh peneliti terdahulu adalah pengembangan bahan ajar BIPA berbasis budaya, baik budaya lokal maupun nasional. Sudana et al., (2019) mengembangkan bahan ajar BIPA berbasis budaya Bali. (Pangesti \& 
Wurianto, 2018) juga Suher dan (Suher, 2017) mengembangkan bahan ajar BIPA berbasis budaya Jawa Timur. Pemanfaatan budaya Jawa Tengah dalam bahan ajar BIPA dikembangkan oleh (Murtianis et al., 2019), (Saddhono et al., 2020) dan Nurlina et al., (2017). Tanwin \& Rosliani, (2020) juga mengembangkan bahan ajar BIPA berbasis budaya lokal. Sedangkan Budiana et al., (2018) mengembangkan buku teks BIPA Berbasis multikulturalisme. Tiga penelitian lain yang terkait dengan pengembangan bahan ajar BIPA berbasis budaya adalah Ningsih, (2020) yang memanfaatkan unsur budaya dalam kumpulan cerita pendek, Siroj (2018) mengembangkan bahan ajar ICT berbasis sosial budaya, dan Tupan (2019) mengembangkan bahan ajar BIPA yang bermuatan budaya Indonesia.

Berdasarkan studi pendahuluan terhadap bahan ajar BIPA yang dihasilkan oleh para peneliti terdahulu di atas, diketahui bahwa bahan ajar BIPA daring belum banyak dikembangkan. Sementara itu, terdapat kebutuhan mendesak terhadap bahan ajar BIPA daring akibat pembelajaran tatap muka ditiadakan. Dosen dan mahasiswa yang melakukan pembelajaran di tempat terpisah membutuhkan bahan ajar BIPA tersebut. Mahasiswa BIPA yang berada di tempat jauh, terutama yang berada luar negeri memerlukan bahan ajar BIPA daring karena pembelajaran BIPA dilakukan secara daring. Terkait dengan itu, dalam penelitian dikembangkan bahan ajar BIPA daring untuk pebelajar tingkat pemula rendah. Dipilihnya pemula rendah karena mayoritas pebelajar BIPA berada pada tingkat kemahiran ini (Suyitno et al., 2019). Oleh karena itu, tujuan penelitian pengembangan ini adalah menghasilkan bahan ajar BIPA daring untuk pebelajar tingkat pemula rendah yang memiliki kelayakan untuk digunakan. Dengan dihasilkannya bahan ajar ini diharapkan dapat membantu menyelesaikan permasalahan ketiadaan bahan ajar BIPA daring untuk pebelajar tingkat pemula yang dihadapi oleh dosen dan mahasiswa.

\section{LANDASAN TEORI}

Bahan ajar adalah seperangkat sarana yang berisikan materi, metode, dan cara mengevaluasi yang didesain secara sistematis dan menarik untuk mencapai tujuan pembelajaran yang diharapkan, mencapai kompetensi atau sub kompetensi dengan segala kompleksitasnya (C. Widodo \& Jasmadi., 2008). Dikemukakan lebih lanjut bahwa tujuan pengembangan bahan ajar dimaksudkan untuk 1) membantu proses pembelajaran yang disesuaikan dengan kurikulum, 2) menjadi pendukung dan pelengkap buku-buku teks lainnya, 3) mempermudah peserta didik dan pendidik dalam memiliki sumber utama dalam pembelajaran, dan 4) mempermudah pendidik dalam menyesuaikan pembelajaran yang dilaksanakannya. Dengan demikian, ciri-ciri bahan ajar yang baik adalah sesuai tujuan (kurikulum dan silabus), ada tugas dikerjakan pebelajar, memperhatikan minat pebelajar, memperhatikan kegiatan komunikasi, memperhatikan cara belajar, memperhatikan cara penyajian, dan mengandung evaluasi terhadap prosedur dan isi pelajaran (Lina Tiawati, 2018).

Pengembangan bahan ajar perlu memperhatikan prinsip-prinsip pengembangan. (Mbulu $\&$ Suhartono., 2004) menyatakan bahwa ada tujuh prinsip untuk mengembangkan bahan ajar. Tujuh prinsip tersebut adalah (1) bertahap, artinya ada prosedur tertentu untuk mengembangkan bahan ajar, (2) menyeluruh, artinya cara pandang melihat bahan ajar adalah menyeluruh bukan per bagian saja, (3) sistematik, artinya suatu bahan ajar perlu disusun secara bersistem, (4) luwes, artinya mampu memasukkan hal-hal baru ketika pengimplementasiannya di lapangan, (5) validitas keilmuan, artinya materi pada bahan ajar mampu dipertanggungjawabkan sisi keilmuannya, (6) berorientasi pada pelajar, artinya pengembangan dilakukan sesuai dengan analisis kebutuhan pelajar, dan (7) berkesinambungan, artinya proses pengembangan bahan ajar saling berhubungan, mulai dari merancang, mengembangkan, menguji, dan memanfaatkan (menerapkan). 
Pengembangan adalah proses menerjemahkan spesifikasi produk ke dalam bentuk fisik (Seels \& Richey, 1994). Menurut Kamus Besar Bahasa Indonesia, (2008), pengembangan adalah proses, cara, perbuatan menjadikan sesuatu lebih baik, dan lebih sempurna. Berdasarkan dua rujukan tersebut dapat dikatakan bahwa pengembangan bermakna sebagai perbuatan menyediakan sesuatu yang sebelumnya tidak tersedia menjadi tersedia atau melakukan perbaikan-perbaikan dari sesuatu yang tersedia menjadi lebih sesuai, lebih tepat guna dan lebih berdaya guna.

Pengembangan bahan ajar adalah suatu proses yang sistematis dalam mengidentifikasi, mengembangkan dan mengevaluasi isi dan strategi pembelajaran yang diarahkan untuk mencapai tujuan pembelajaran secara lebih efektif dan lebih efisien. Tujuan mengembangkan bahan ajar adalah untuk (1) mempersiapkan kegiatan pembelajaran dalam berbagai situasi, supaya pembelajaran dapat berlangsung secara optimal, (2) meningkatkan motivasi pengajar untuk mengelola kegiatan belajar mengajar, dan (3) mempersiapkan kegiatan belajar mengajar dengan mengisi bahan-bahan yang selalu baru, ditampilkan dengan cara baru dan dilaksanakan dengan strategi pembelajaran yang baru pula.

Bahan ajar yang baik adalah bahan ajar yang berkualitas. Menurut UNESCO dalam (Susanto, 2008) syarat-syarat bahan ajar yang berkualitas sebagai berikut. 1) Bahan ajar memiliki peran penting untuk mewujudkan pendidikan yang merata dan berkualitas tinggi. 2) Bahan ajar merupakan produk dari proses yang lebih besar dari pengembangan kurikulum. 3) Isi bahan ajar memasukkan prinsip-prinsip hak asasi manusia, mengintegrasikan proses pedagogis yang mengajarkan secara damai terhadap penyelesaian konflik, kesetaraan gender, non-diskriminasi, praktik-praktik dan sikap-sikap lain yang selaras dengan kebutuhan untuk belajar hidup bersama. 4) Bahan ajar memfasilitasi pembelajaran untuk mendapatkan hasilhasil spesifik yang dapat diukur dengan memperhatikan berbagai perspektif, gaya pembelajaran, dan modalitas berbeda (pengetahuan, keterampilan, dan sikap). 5) Memperhitungkan level konseptual, lingkungan linguistik, latar belakang dan kebutuhan pebelajar di dalam membentuk isi dan mendesain model pembelajaran. 6) Bahan ajar memfasilitasi pembelajaran yang dapat mendorong partisipasi dan pengalaman secara merata dan setara oleh semua pebelajar yang terlibat dalam proses pembelajaran. 7) Bahan ajar dapat dijangkau dari sisi biaya, memiliki daya tahan lama dan dapat diakses oleh semua pebelajar.

Bahan ajar BIPA daring (dalam jaringan) adalah bahan ajar BIPA yang didesain untuk digunakan pembelajaran BIPA secara virtual. Pemakaian bahan ajar BIPA daring bertumpu pada jaringan internet, moda pembelajaran berbasis aplikasi dan perangkat elektronik seperti komputer, laptop, dan gawai. Pemakaian bahan ajar daring mengandalkan penggunaan teknologi informasi dan jaringan yang berupa internet (Choudhury \& Pattnaik, 2020). Dalam menggunakan bahan ajar daring, biasanya guru menggabungkan moda pembelajaran asinkronus dan sinkronus (Moorhouse, 2020). Dalam pembelajaran sinkronus dosen menggunakan konferensi video selama pembelajaran berlangsung. Sedangkan dalam pengajaran asinkronus, dosen memberikan materi melalui web, email atau pesan yang dikirimkan ke forum komunitas. Oleh karena itu, dalam pembelajaran daring dosen perlu menguasai teknologi dan moda virtual yang digunakan dalam pembelajaran daring (Corbera et al., 2020).

Bahan ajar yang baik adalah bahan ajar yang dapat memenuhi tuntutan standar kompetensi atas kompetensi dasar yang ditentukan. Dari tuntutan ini, berarti bahwa materi pembelajaran yang dipilih untuk diajarkan oleh dosen di satu pihak dan harus dapat dipelajari mahasiswa di lain pihak. Oleh karena itu, hendaknya bahan ajar mengarah ke pemenuhan kompetensi yang ditetapkan dalam kurikulum. Kurikulum BIPA dikembangkan secara berjenjang sesuai dengan tingkat kemahiran berbahasa pebelajar. Dengan kata lain, pengembangan bahan ajar perlu disesuiakan dengan tingkat kemahiran berbahasa pebelajarnya. 
Tingkat kemahiran berbahasa pebelajar BIPA secara umum diklasifikasikan menjadi tiga tingkat kemahiran berbahasa, yaitu tingkat pemula, menengah dan lanjut (Susanto et al., 2020). Tiap-tiap tingkat kemahiran dibagi lagi menjadi dua, yaitu rendah dan tinggi. Sebagai contoh, tingkat pemula diklasifikasikan menjadi pemula rendah dan pemula tinggi. Berdasarkan acuan kurikulum CEFR (Council of Europe, 2001; Little, 2006), tingkat Pemula rendah tersebut diberi nama level A1 dan pemula tinggi level A2. Sementara itu berdasarkan acuan kurikulum ACTFL (2012) tingkat pemula dibagi menjadi tiga, yaitu pemula rendah (Novice Low), pemula madya (Novice Mid) dan pemula tinggi (Novice High). Menurut acuan kurikulum Standar Kompetensi Lulusan (SKL), tingkat pemula dibagi menjadi dua tingkat yaitu kemahiran terbatas (BIPA 1) dan kemahiran marginal (BIPA 2). Ketiga acuan kurikulum itulah yang sering dijadikan rujukan pengembangan bahan ajar BIPA (G. Susanto et al., 2020).

\section{METODE PENELITIAN}

Pada metode penelitian ini dikemukakan dua kegiatan, yaitu prosedur mengembangkan bahan ajar BIPA dan menilai kelayakan bahan ajar. Kedua kegiatan penelitian ini dijelaskan sebagai berikut.

\section{Prosedur pengembangan bahan ajar BIPA daring}

Prosedur pengembangan yang digunakan dalam penelitian ini adalah model (Gall et al., 2007). Model pengembangan ini terdiri atas sepuluh tahap pengembangan. Kesepuluh tahap pengembangan tersebut adalah (1) analisis kebutuhan dan pengumpulan informasi awal, (2) perencanaan penelitian, (3) pengembangan format produk awal, (4) uji coba produk pertama, (5) revisi produk pertama, (6) uji coba kelompok kecil, (7) revisi produk kedua, (8) uji coba kelompok besar, (9) revisi akhir, dan (10) penyempurnaan produk akhir dan diseminasi. Dipilihnya prosedur Borg dan Gall ini didasari oleh pertimbangan bahwa model ini memandu langkah-langkah pengembangan produk secara detail dan komprehensif. Ibarat saringan tepung, model pengembangan Gall et al. ini menyajikan banyak lapisan dengan tingkat kerapatan yang berjenjang, sehingga dapat menghasilkan tepung yang benar-benar lembut atau halus. Aktivitas sepuluh langkah pengembangan dalam penelitian ini dijelaskan berikut.

Pertama, melakukan analisis kebutuhan dan mengumpulkan informasi awal. Dalam proses ini peneliti mengkaji beberapa bahan ajar BIPA tingkat pemula untuk menemukan topiktopik bahasan, cara penyajian materi, dan model latihannya. Bahan ajar BIPA yang dikaji antara lain Let's Speak Indonesian: Ayo Berbahasa Indonesia 1 yang dikembangkan oleh (Rafferty et al., 2014); Bahan Ajar BIPA Tingkat Dasar 1 (Susanto et al., 2020) Living Indonesian: Textbook BIPA for Beginning Level Intensive Indonesian Language Course (Widodo et al., 2011) Sahabatku Indonesia oleh Muliastuti \& Camila, (2016), dan beberapa bahan ajar BIPA lain yang didesain untuk pebelajar tingkat pemula. Peneliti juga melakukan wawancara informal kepada para dosen dan/atau instruktur BIPA di Universitas Negeri Malang yang sudah berpengalaman mengajar BIPA tingkat pemula. Selain itu, peneliti juga meminta refleksi kepada para alumni program BIPA dan membaca beberapa hasil penelitian terdahulu yang berkaitan dengan penelitian ini.

Kedua, merencanakan penelitian yang dilakukan dengan cara menentukan tujuan pengembangan bahan ajar BIPA. Berdasarkan tingkat urgensi kebutuhan, tujuan pengembangan bahan ajar BIPA ini diarahkan pada bahan ajar BIPA daring untuk pebelajar tingkat pemula. Bahan ajar ini didesain untuk mencukupi kebutuhan pembelajaran selama satu semester. Dalam satu semester pembelajaran BIPA dibagi menjadi 16 kali pertemuan, dengan pembagian satu kali untuk pengantar dan penjelasan umum perkuliahan, untuk ujian tengah semester, dan untuk ujian akhir semester, serta 13 kali pertemuan untuk menyajikan materi. Dengan demikian bahan ajar BIPA yang dikembangkan dimaksudkan untuk memenuhi kebutuhan pembelajaran untuk 13 kali pertemuan. Satu kali pertemuan disiapkan satu unit 
pelajaran. Pada tahap ini ditentukan topik setiap unit pelajaran dan direncanakan struktur penyajian bahan ajar untuk setiap unitnya, serta menentukan validator ahli.

Ketiga, mengembangan produk awal yang dilakukan dengan cara menguraikan tiga belas unit pelajaran. Dalam menguraikan unit-unit pelajaran tersebut selain dijabarkan materi pelajaran juga dimasukkan gambar-gambar yang mendukung uraian tersebut. Setelah prototipe bahan ajar terwujud, selanjutnya bahan ajar tersebut divalidasikan kepada pakar BIPA dan dosen BIPA yang berpengalaman mengajar BIPA tingkat pemula. Atas masukkan pakar BIPA dan pengajar BIPA, bahan ajar BIPA daring untuk pebelajar tingkat pemula siap diujicobakan di kelompok kecil.

Keempat, uji coba produk pertama dilakukan pada bulan April 2020 kepada satu mahasiswa Amerika yang melakukan pembelajaran daring. Dalam uji coba ini, disiapkan angket untuk mahasiswa. Prosedur penyusunan angket dilakukan dengan membuat daftar pertanyaan untuk mencari tahu pendapat mahasiswa tentang kesesuaian bahan ajar BIPA. Angket berisi 15 pernyataan tentang tingkat kesulitan, ragam dan penyajian bahan ajar. Pilihan jawaban angket memiliki rentangan 1-4 dengan makna sangat setuju (1) sampai dengan sangat tidak setuju (4). Setelah kalimat-kalimat pernyataan disusun, selanjutkan angket diterjemahkan dalam bahasa Inggris. Berikutnya angket di unggah di Google Drive dan pranalanya diedarkan kepada pelaku uji coba produk. Hasil angket dianalisis sebagai bekal untuk memperbaiki produk.

Kelima, pada tahap ini dilakukan revisi produk pertama. Atas masukan dosen yang menggunakan prototipe produk dan hasil angket mahasiswa diketahui bahwa tingkat kesulitan bahan ajar ini sudah sesuai dengan tingkat kemahiran pebelajar tingkat pemula. Namun demikian ada tiga saran penting untuk perbaikan. Ketiga saran tersebut adalah 1) tiap unit pelajaran tidak perlu berisi topik yang berbeda, Sebaiknya topik yang sama dapat diulang pada unit selanjutnya supaya mahasiswa memiliki kesempatan menggunakan kosakata, frasa dan kalimat di unit yang lain. 2) Bahan ajar akan lebih baik apabila diberi fasilitas bahasa Inggris, dan 3) Setiap unit perlu disertai penjelasan tata bahasa. Setelah produk diperbaiki berdasarkan isian angket, produk kembali divalidasi oleh validator dan disempurnakan sebelum uji coba kedua. Masukan validator pada tahap uji coba adalah (1) kata-kata yang digunakan dalam bahan ajar perlu disederhanakan, (2) topik yang dibicarakan dalam bahan ajar bersifat konkret, dan (3) diperlukan strategi pengulangan pemakaian kata, frasa dan kalimat dari unit pelajaran sebelumnya ke unit pelajaran berikutnya.

Keenam, uji coba kedua dilakukan pada tanggal 8 sampai dengan tanggal 19 Juni 2020 kepada kelompok kecil yang terdiri atas enam mahasiswa yang berasal dari Amerika, Panama, Korea, Mesir, Rusia, dan Thailand. Sama seperti uji coba pertama, pada uji coba kelompok kecil juga menggunakan angket yang diberikan kepada mahasiswa. Format angket untuk uji coba kedua sama dengan format angket pada uji coba pertama. Hal ini dimaksudkan untuk mendapatkan konsistensi penilaian kelayakan terhadap aspek bahan ajar yang diujicobakan. Angket tersebut bertujuan untuk mengetahui keefektifan dan kesesuaian bahan ajar yang diujicobakan. Angket yang sudah dikumpulkan dianalisis sebagai bekal untuk memperbaiki produk bahan ajar.

Ketujuh, revisi produk kedua dilakukan setelah uji coba kelompok kecil. Setelah angket dianalisis, produk diperbaiki dan divalidasi ulang seperti tahap revisi produk pertama. Revisi kedua ini bertujuan menyempurnakan kekurangan-kekurangan produk berdasarkan hasil analisis angket dan saran validator.

Kedelapan, uji coba produk ketiga dilakukan pada tanggal 3 sampai dengan 28 Agustus 2020 dengan melibatkan 73 mahasiswa asing dari 26 negara. Sebagaimana uji coba sebelumnya, pada uji coba ketiga ini, peneliti juga mendistribusikan angket yang sama kepada para mahasiswa. Hasil 
angket pada tahap uji coba ketiga inilah yang digunakan untuk menilai kelayakan bahan ajar BIPA daring untuk pebelajar tingkat pemula.

Kesembilan, peneliti melakukan revisi produk terakhir dengan memperbaiki produk bahan ajar secara utuh dari semua aspeknya, termasuk mendesain sampul, menambahkan kata pengantar. Pada tahap diperoleh hasil bahan ajar BIPA daring untuk pebelajar tingkat pemula.

Terakhir, langkah kesepuluh dari proses pengembangan adalah penyebarluasan produk atau melakukan diseminasi. Pada tahap terakhir ini, produk bahan ajar BIPA daring dikirimkan ke penerbit anggota IKAPI untuk pengurusan ISBN. Setelah bahan ajar BIPA ini terbit dengan memiliki ISBN, selanjutnya bahan ajar BIPA ini didiseminasi untuk umum dengan cara diunggah ke repositori Universitas Negeri Malang. Hasil pengembangan bahan ajar BIPA ini dapat diakses secara gratis dengan melakukan penelusuran lewat mesin pencari seperti Google Search.

\section{Uji kelayakan bahan ajar BIPA daring}

Untuk mengetahui kelayakan bahan ajar BIPA daring untuk pebelajar tingkat pemula, peneliti melakukan kegiatan-kegiatan di bawah ini.

1) Menyusun angket kelayakan isi bahan ajar BIPA daring (angket 1). Angket kelayakan isi ini didistribusikan kepada para pebelajar BIPA. Angket terdiri atas 15 pertanyaan dalam bahasa Inggris. Penggunaan bahasa Inggris dalam angket dimaksudkan untuk memudahkan partisipan mengisi angket tersebut. Hal ini dilakukan karena partisipan tidak semuanya berlatar belakang bahasa pertama bahasa Inggris. Angket penelitian disajikan pada tabel 1 berikut.

Tabel 1: Angket 1 kelayakan isi

Student Perception Questionnaire on Feasibility of Teaching Materials

\section{Instruction on how to fill out the questionnaire}

This questionnaire asks for information about the beginner BIPA teaching material, please answer the following questions on the basis of the facts of your experience during the online course.

Alternative

a) Strongly agree

b) Agree

c) Disagree

d) Strongly disagree

Tabel 1

Angket Kelayakan Isi (List of Questions)

\begin{tabular}{llllllll}
\hline NO & \multicolumn{1}{c}{ QUESTIONS } & ANSWER \\
\hline 1 & As a beginner student, the difficulty of this teaching material is suitable for me. & 1 & 2 & 3 & 4 \\
\hline 2 & $\begin{array}{l}\text { The cultural elements found in this teaching material help me to understand } \\
\text { Indonesian culture. }\end{array}$ & 1 & 2 & 3 & 4 \\
& The topics in this teaching material help me to use the Indonesian in a real way. & 1 & 2 & 3 & 4 \\
\hline 3 & Teaching materials emphasizes language practice rather than theory. & 1 & 2 & 3 & 4 \\
\hline 4 & The English used in teaching materials facilitates me to understand the content \\
of the material and improve the use of the Indonesian. & 1 & 2 & 3 & 4 \\
\hline 5 & New vocabularies provided for each unit is suitable for learning in 2 hours. & 1 & 2 & 3 & 4 \\
\hline 6 & $\begin{array}{l}\text { The mini-dictionary at the end of the unit helped me to review the vocabulary } \\
\text { lists targeted in each unit of study. }\end{array}$ & 1 & 2 & 3 & 4 \\
\hline 7 & $\begin{array}{l}\text { The grammar notes in each unit of study help me to understand the concept of } \\
\text { Indonesian grammar. }\end{array}$ & 1 & 2 & 3 & 4 \\
\hline 8 &
\end{tabular}




\begin{tabular}{|c|c|c|}
\hline 9 & $\begin{array}{l}\text { The exercises given in each session helped me to put my Indonesian knowledge } \\
\text { into practice. }\end{array}$ & $1 \quad 2 \quad 3 \quad 4$ \\
\hline 10 & $\begin{array}{l}\text { The teaching materials have helped me to practice how to think critically and } \\
\text { creatively in Indonesian. }\end{array}$ & $\begin{array}{llll}1 & 2 & 3 & 4\end{array}$ \\
\hline 11 & $\begin{array}{l}\text { The pictures used in the lesson help me to understand the material and practice } \\
\text { Indonesian. }\end{array}$ & $1 \quad 2 \quad 3 \quad 4$ \\
\hline 12 & $\begin{array}{l}\text { The objective description of the lesson in each unit of study helps me to } \\
\text { understand the purpose of the study itself. }\end{array}$ & $\begin{array}{llll}1 & 2 & 3 & 4\end{array}$ \\
\hline 13 & The quiz is given to measure my ability and skills in Indonesian. & $1 \quad 2 \quad 3 \quad 4$ \\
\hline 14 & $\begin{array}{l}\text { The materials presented in this teaching material motivated me to learn } \\
\text { Indonesian. }\end{array}$ & $\begin{array}{llll}1 & 2 & 3 & 4 \\
\end{array}$ \\
\hline 15 & $\begin{array}{l}\text { The study units helped me to be able to do spoken and written language in } \\
\text { Indonesian }\end{array}$ & $1 \quad 2 \quad 3 \quad 4$ \\
\hline
\end{tabular}

2) Mengemas angket 1 dalam Google Drive dan menyebarkannya angket kepada para mahasiswa pengguna produk bahan ajar ini.

3) Menyusun angket 2, yaitu kelayakan bahan ajar BIPA daring dari aspek kebahasaan (pertanyaan 1-5) dan penyajian (pertanyaan 6-10). Angket ini diedarkan kepada lima orang yang terdiri ada dua pakar BIPA dan tiga pengajar BIPA. Angket penelitian dari aspek kebahasaan dan penyajian disajikan pada tabel 2 berikut.

Tabel 2

Angket Kelayakan Bahasa dan Sajian Bahan Ajar BIPA Daring

\begin{tabular}{|c|c|c|}
\hline NO & $\begin{array}{l}\text { PERTANYAAN } \\
\end{array}$ & JAWABAN \\
\hline 1 & $\begin{array}{l}\text { Bahasa Indonesia yang digunakan dalam bahan ajar BIPA daring ini sesuai untuk } \\
\text { pebelajar tingkat pemula rendah. }\end{array}$ & $\begin{array}{llll}1 & 2 & 3 & 4\end{array}$ \\
\hline 2 & $\begin{array}{l}\text { Bentukan kosakata bahasa Indonesia yang digunakan dalam bahan ajar BIPA } \\
\text { daring ini cocok untuk pebelajar tingkat pemula rendah. }\end{array}$ & $123 \quad 34$ \\
\hline 3 & $\begin{array}{l}\text { Struktur kalimat bahasa Indonesia yang digunakan dalam bahan ajar BIPA daring } \\
\text { ini cocok untuk pebelajar tingkat pemula rendah. }\end{array}$ & 12234 \\
\hline 4 & $\begin{array}{l}\text { Pemakaian bahasa Inggris dalam bahan ajar BIPA daring ini cocok untuk } \\
\text { pebelajar tingkat pemula rendah. }\end{array}$ & $\begin{array}{llll}1 & 2 & 3 & 4\end{array}$ \\
\hline 5 & $\begin{array}{l}\text { Bahasa Indonesia yang digunakan dalam bahan ajar BIPA daring ini } \\
\text { mencerminkan ragam bahasa Indonesia komunikatif. }\end{array}$ & $\begin{array}{llll}1 & 2 & 3 & 4\end{array}$ \\
\hline 6 & Penyajian bahan ajar BIPA daring ini terstruktur dengan jelas. & 23 \\
\hline 7 & $\begin{array}{l}\text { Urutan penyajian mulai dari tujuan, materi, latihan, tata bahasa, dan kamus mini } \\
\text { menunjukkan karakteristik bahan ajar BIPA daring ini. }\end{array}$ & 23 \\
\hline 8 & $\begin{array}{l}\text { Urutan penyajian mulai dari tujuan, materi, latihan, tata bahasa, dan kamus mini } \\
\text { menunjukkan alur yang runtut untuk menggunakan bahan ajar BIPA daring ini }\end{array}$ & 123 \\
\hline 9 & $\begin{array}{l}\text { Pembagian } 13 \text { unit pelajaran untuk } 13 \text { kali pertemuan memandu pelaksanaan } \\
\text { pembelajaran. }\end{array}$ & $\begin{array}{llll}1 & 2 & 3 & 4\end{array}$ \\
\hline 10 & $\begin{array}{l}\text { Penyajian gambar-gambar dalam bahan ajar BIPA ini proporsional dan } \\
\text { fungsional. }\end{array}$ & $123 \quad 34$ \\
\hline
\end{tabular}

4) Menentukan panduan analisis kelayakan bahan ajar. Penilaian kelayakan bahan ajar didasarkan pada kelayakan isi, bahasa, dan penyajian. Untuk menentukan kelayakan dilakukan tiga langkah berikut.

a) Membuat konversi jawaban angket menjadi skor. Konversi jawaban angket menjadi skor ditetapkan dalam tabel 3 berikut.

Tabel 3

Panduan Penyekoran

\begin{tabular}{cc}
\hline JAWABAN ANGKET & SKOR \\
\hline 1 & 4 \\
\hline 2 & 3 \\
\hline 3 & 2 \\
\hline 4 & 1 \\
\hline
\end{tabular}

b) Menentukan persentase jawaban angket. Penghitungan persentase tiap angket dilakukan dengan rumus berikut. 
$\mathrm{P}=\mathrm{f} / \mathrm{n} \times 100 \%$

Keterangan:

$\mathrm{P}=$ presentase kelayakan

$\mathrm{f}=$ frekuensi setiap jawaban.

Frekuensi setiap jawaban berupa rerata skor yang diperoleh dari perkalian skor isian angket, jumlah soal, dan jumlah partisipan.

$\mathrm{n}=$ jumlah skor ideal.

Jumlah skor diperoleh dari skor maksimal isian angket, yaitu 4 dikalikan dengan jumlah soal dan jumlah partisipan.

c) Hasil presentasi selanjutnya ditafsirkan dengan panduan kriteria kelayakan, seperti pada tabel 4 berikut.

Tabel 4

Kriteria Kelayakan

\begin{tabular}{ll}
\hline Presentase & Tringkat Kelayakan \\
\hline $81 \%-100 \%$ & Sangat layak \\
\hline $61 \%-80 \%$ & Layak \\
\hline $41 \%-60 \%$ & Cukup layak \\
\hline $21 \%-40 \%$ & Kurang layak \\
\hline $0 \%-20 \%$ & Sangat tidak layak \\
\hline & $\quad$ (Arikunto, 2010)
\end{tabular}

\section{PEMBAHASAN}

Dalam hasil dan pembahasan dikemukakan karakteristik produk hasil pengembangan dan tingkat kelayakan bahan ajar BIPA daring.

\section{Bahan ajar BIPA daring untuk pebelajar tingkat pemula}

Bahan ajar BIPA daring untuk pebelajar tingkat pemula hasil pengembangan memiliki karakteristik sebagai berikut.

1) Bahan ajar BIPA daring hasil pengembangan ini memiliki ISBN: 978-602-470-260-1 dan dapat diakses oleh publik secara gratis.

Bahan ajar BIPA hasil pengembangan ini memiliki struktur yang terdiri atas sampul, kata pengantar, daftar isi dan unit-unit pelajaran. Wujud sampul bahan ajar yang dicetak di kertas ukuran A4 sebagai berikut.

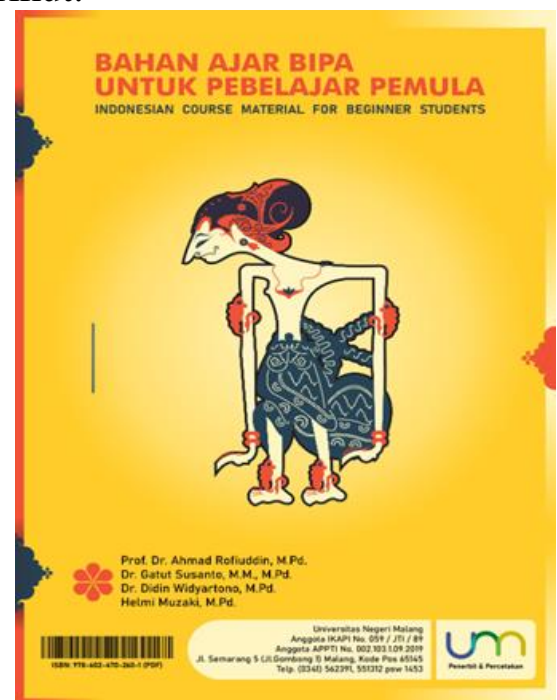

Sementara itu kata pengantar ditulis dalam bahasa Inggris karena bahan ajar ini didesain untuk pebelajar tingkat pemula rendah. Penggunaan bahasa Inggris dalam kata pengantar untuk memudahkan pengguna bahan ajar memahami pesan dalam pengantar 
tersebut. Daftar isi diberikan untuk membantu mahasiswa mencari unit atau tema-tema yang dicari berada di halaman berapa.

Unit pelajaran 1 sampai dengan unit pelajaran 13 dipaparkan dalam 66 halaman. Setiap unit pelajaran dilengkapi dengan ringkasan materi berupa PPT. Unit pelajaran 1 sampai dengan 13 digunakan mahasiswa untuk melaksanakan pembelajaran secara asinkronus. Sementara untuk pembelajaran sinkronus, mahasiswa dan dosen menggunakan tayangan PPT. Dengan demikian dapat dikatakan bahwa bahan ajar BIPA daring terdiri atas bahan ajar asinkronus dan sinkronus. Hal ini sejalan dengan pendapat (Moorhouse, 2020) bahwa dalam menggunakan bahan ajar daring, guru biasanya menggabungkan moda pembelajaran asinkronus dan sinkronus.

Yang membedakan bahan ajar asinkronus dan sinkronus adalah waktu interaksi dan komunikasi mahasiswa dengan dosen. Dalam bahan ajar asinkronus, interaksi dan komunikasi antara dosen dan mahasiswa berlangsung pada waktu yang berbeda. Sementara itu dalam bahan ajar sinkronus, interaksi dan komunikasi antara mahasiswa dan dosen berlangsung pada waktu yang bersamaan (Oztok et al, 2013). Dengan demikian dapat dikemukakan bahwa bahan ajar daring dibedakan menjadi bahan ajar asinkronus dan sinkronus, dan kedua bahan ajar inilah yang menjadi penanda pembelajaran yang dilaksanakan secara daring. Desain bahan ajar BIPA secara asinkronus dan sinkronus tersebut sesuai dengan karakter pembelajaran daring. Hal ini sesuai dengan pendapat Choudhury dan Pattnaik (2020) bahwa pembelajaran daring bertumpu pada internet, moda pembelajaran berbasis aplikasi dan perangkat elektronik seperti komputer, laptop, dan gawai. Dengan demikian, pembelajaran daring tidak bisa dilakukan tanpa memanfaatkan teknologi informasi dan internet.

Pengembangan bahan ajar BIPA daring yang berwujud bahan ajar asinkronus dan sinkronus tersebut dapat dipahami sebagai bentuk spesifikasi produk bahan ajar BIPA. Bentuk produk yang spesifik tersebut merupakan hasil dari sebuah proses menerjemahkan spesifikasi produk ke dalam bentuk fisik (Seels \& Richey, 1994). Selain itu, hasil pengembangan bahan ajar BIPA daring tersebut merupakan sebuah Tindakan konkret menyediakan sesuatu yang sebelumnya tidak tersedia menjadi tersedia.

2) Isi bahan ajar BIPA hasil pengembangan ini dapat diuraikan sebagai berikut.

a) Bahan ajar asinkronus ini terdiri atas tiga belas unit pelajaran. Ketiga belas unit pelajaran tersebut disesuaikan dengan kebutuhan pembelajaran BIPA daring selama satu semester. Tiap unit pelajaran dirancang untuk pembelajaran asinkronus selama 120 menit. Sementara itu, materi asinkronus dilengkapi dengan materi PPT yang dirancang untuk pembelajaran secara sinkronus selama 60 menit. Pembagian tiga belas unit pelajaran tersebut didasarkan pada pertimbangan 16 kali pertemuan dalam satu semester. 16 kali pertemuan tersebut dibagi menjadi satu pertemuan di awal digunakan untuk menjelaskan tata cara perkuliahan dan saling berkenalan. Dua kali pertemuan untuk ujian tengah semester dan ujian akhir semester. Sisanya, 13 kali pertemuan untuk menyampaikan materi pelajaran.

b) Topik yang sama diuraikan di dua unit pelajaran. Unit pelajaran satu dan dua berisi topik berkenalan, unit pelajaran tiga dan empat bertopik kampus, unit pelajaran lima berisi topik rumah, unit pelajaran enam dan tujuh memuat topik tentang kantor, unit pelajaran sembilan dan sepuluh topiknya tentang kantin, dan unit pelajaran sebelas dan dua belas berisi topik taman, serta unit pelajaran tiga belas berisi topik tentang pasar.

Pemakaian topik yang sama pada dua unit pelajaran didasarkan pada masukan mahasiswa dan guru sewaktu melakukan uji coba produk. Disarankan oleh mahasiswa dan guru sebaiknya tiap unit pelajaran tidak selalu berisi daftar kosakata baru. Sebaiknya tiap-tiap unit pelajaran didesain seperti spiral, ada bagian pelajaran yang 
diulang atau dimantapkan di unit pelajaran berikutnya. Atas masukan tersebut, akhir tema unit pelajaran diulang pada unit yang lain. Pengulangan tersebut dimaksudkan untuk memberikan peluang menggunakan kosakata secara berulang. Pemakaian kosakata secara berulang tersebut sesuai dengan pendapat (Susanto, 2015) yang menyatakan prinsip mengembangkan dan mengajarkan kosakata BI kepada pebelajar asing harus memungkinkan pebelajar sering menggunakan kosakata yang diajarkan. Dengan sering menggunakan kosakata pebelajar akan mudah ingat kosakata tersebut.

c) Struktur tiap unit pelajaran terdiri atas topik yang dijabarkan menjadi empat bagian, yaitu a) tujuan, b) uraian materi, c) latihan, d) catatan tata bahasa, dan e) kamus mini yang ada padanan kata dalam bahasa Inggris.

Pemakaian kelima bagian pengembangan pada tiap unit pelajaran menunjukkan bahan ajar dikemas secara padat dan terstruktur. Pengembangan bahan ajar di atas dapat dikatakan terstruktur karena nama-nama sub unit pelajaran pada tiap unit pelajaran memiliki pola yang tetap. Konsistensi terhadap pemakaian pola pengembangan menggambarkan adanya tahapan dan system yang digunakan. Model pengembangan bahan ajar yang bertahap dan bersistem ini sejalan dengan prinsip-prinsip pengembangan bahan ajar yang dikemukakan oleh Mbulu \& Suhartono (2004).

Dituliskannya tujuan pelajaran pada bagian awal tiap unit pelajaran dimaksudkan untuk memandu dan membatasi luasan materi. Luasan materi ini terkait erat dengan kompetensi yang hendak dicapai dalam tiap unit pelajaran. Dikemukakan oleh Widodo \& Jasmadi (2008) bahwa tujuan pengembangan bahan ajar dimaksudkan untuk membantu mencapai tujuan kurikulum dan mempermudah peserta didik dalam memiliki sumber utama pembelajaran, serta mempermudah pendidik dalam menyesuaikan pembelajaran yang dilaksanakannya. Ditambahkan oleh Tiawati (2018) bahwa bahan ajar yang baik adalah bahan ajar yang sesuai kurikulum, ada tugas-tugas yang dikerjakan pebelajar, memperhatikan cara penyajian, mengandung prosedur dan isi pelajaran.

Uraian materi yang dikemas dalam bentuk percakapan, latihan, catatan tatabahasa, dan kamus mini, lalu dilanjutkan ke aktivitas praktik berbicara di kelas sinkronus dimaksudkan untuk memandu prosedur pelaksanaan pendekatan komunikatif. Dalam pelaksanaan pendekatan komunikatif di kelas pembelajaran bahasa kedua atau asing disaran menggunakan urutan (1) berlatih berbicara (lewat materi percakapan), (2) tanyajawab berdasarkan percakapan (latihan), (3) menjelaskan makna dan struktur (catatan tatabahasa), dan (4) praktik berbicara (menggunakan daftar kosakata).

d) Pada bagian kamus mini juga disediakan tempat untuk menulis padanan kata dalam bahasa pertama yang kuasai pembelajar.

Desain kamus mini yang berisi daftar kosakata target dalam tiga bahasa, yaitu bahasa Indonesia, Inggris dan tempat kosong untuk mengakomodasi bahasa pertama mahasiswa didasarkan pada saran pebelajar sewaktu uji coba materi. Pebelajar yang melakukan uji coba berasal dari berbagai negara dan tidak semuanya menguasai bahasa Inggris. Oleh karena itu, mereka menyarankan ada tempat kosong dalam kamus mini supaya mereka bisa menuliskan dalam bahasa yang mereka kuasai. Saran pembelajar tersebut menguatkan pendapat Ellis (1995) bahwa faktor perbedaan individu yang salah satu berkaitan dengan latar belakang bahasa pertama yang dikuasai pebelajar berpengaruh dalam belajar bahasa asing.

e) Ragam bahasa yang digunakan dalam bahan ajar ini ragam komunikatif, yang dapat digunakan dalam situasi komunikasi formal dan informal.

Pemakaian ragam bahasa komunikatif ini disesuaikan dengan pendekatan komunikatif yang digunakan dalam pembelajaran BIPA. Dalam peristiwa komunikasi, 
situasi komunikasi tidak saja formal, tetapi juga informal. Oleh karena itu, situasi formal dan informal keduanya digunakan dalam bahan ajar hasil hasil pengembangan ini supaya pebelajar yang menggunakan bahan ajar ini benar-benar memiliki kompetensi komunikasi. Menurut Canale \& Swain, (1980) kompetensi komunikatif meliputi kompetensi tata bahasa, kewacanaan, sosiolinguistik dan strategis. Kompetensi tata bahasa berkaitan penguasaan kaidah kebahasan yang berlaku, seperti aturan pembentukan kalimat. Kompetensi kewacanaan berkaitan dengan penguasaan piranti kohesi dan aturan-aturan koherensi untuk mengatur makna. Misalnya adanya pengulangan, konsistensi, dan relevansi ide. Kompetensi sosiolinguistik berkaitan dengan penguasaan penggunaan bahasa secara tepat dalam konteks sosiolinguistik yang berbeda. Kompetensi strategis berkaitan dengan penguasaan strategi-strategi verbal dan nonverbal yang digunakan dalam berkomunikasi. Atas dasar pendekatan komunikatif inilah, gambar-gambar, tata bahasa, daftar kosakata, dan kontek pemakaian diorientasikan pada situasi formal dan informal.

f) Bahan ajar BIPA daring ini pelatihan keterampilan berbicara mendapat porsi lebih banyak daripada keterampilan menulis. Perbandingannya adalah $70 \%$ untuk berbicara dan 30\% untuk menulis. Pemberatan pada kemampuan berbicara ini disebabkan oleh penekanan pendekatan komunikasi pada kemahiran berbicara. Selain itu, berdasarkan hasil survei kepada para pebelajar diketahui bahwa 90\% persen dari mereka bertujuan untuk bisa berbicara bahasa Indonesia. Oleh karena itu, bahan ajar BIPA daring hasil pengembangan ini lebih menekankan pada kemahiran berbicara. Hal ini sesuai dengan prinsip berkomunikasi bahwa bahasa yang utama digunakan dalam berkomunikasi adalah bahasa lisan.

g) Bahan ajar BIPA daring disesuaikan dengan karakteristik pebelajar tingkat pemula rendah. Karakteristik tersebut antara lain tampak pada cakupan materi yang berupa kata, frasa dan kalimat berpola sederhana. Selain itu tema-temanya bersifat konkret dan berisi kegiatan yang bersifat rutin. Karakteristik tersebut sesuai dengan level A1 menurut acuan CEFR. Dalam acuan ACTFL, bahan ajar tersebut masuk dalam kategori beginning low atau pemula rendah. Dalam acuan SKL, bahan ajar hasil pengembangan tersebut termasuk kategori BIPA I (Susanto et al., 2020).

Bahan ajar BIPA daring untuk pebelajar tingkat pemula ini hasil dari teknik amati, tiru, dan modifikasi (ATM) yang dilakukan peneliti terhadap beberapa bahan ajar BIPA tingkat pemula yang sudah tersedia. Bahan ajar BIPA yang diamati utamanya adalah: Let's Speak Indonesian: Ayo Berbahasa Indonesia 1, Bahan Ajar BIPA Tingkat Dasar 1, Living Indonesian: Textbook BIPA for Beginning Level Intensive Indonesian Language Course, Sahabatku Indonesia A1. Selain itu, bahan ajar BIPA tingkat pemula lainnya yang diamati adalah: seperti Beginning Indonesian Through Self-Instruction 2, Lentera Indonesia 1, dan Bahasa Tetanggaku: Stage 1.

Hasil pengamatan $(\mathrm{T})$ terhadap bahan ajar BIPA tingkat pemula tersebut menunjukkan 10 hal sebagai berikut.

1) Setiap bahan ajar di setiap unit pelajarannya memiliki struktur yang tetap.

2) Tiap unit pelajaran dikembangkan berdasarkan tema tertentu, misalnya, perkenalan, percakapan di kantor, dan kantin.

3) Tiap unit pelajaran memiliki daftar kosakata baru atau kata sulit.

4) Tiap unit pelajaran menyertakan soal-soal latihan untuk pendalaman materi.

5) Beberapa bahan ajar BIPA menuliskan tujuan di setiap unitnya.

6) Beberapa menyertakan bahasan tata bahasa.

7) Setiap bahan ajar menyertakan gambar-gambar.

8) Bahan ajar BIPA didasarkan pada pendekatan komunikasi. 
9) Bahan ajar BIPA mengandung muatan materi budaya Indonesia.

10) Bahan BIPA tingkat pemula lebih menekankan kemampuan berbicara.

Temuan bahwa bahan ajar tingkat pemula menekankan pada kemampuan berbicara tersebut selaras dengan pendapat Tolimson, (2014) yang menyatakan sejak hari pertama belajar bahasa kedua atau asing, mahasiswa ingin berbicara dalam bahasa tersebut. Oleh karena itu, tidak mengherankan apabila bahan ajar BIPA tingkat pemula lebih menekankan pada keterampilan berbicara. Hal ini dapat dipahami karena bahasa yang dipelajari dan/atau diperoleh oleh seseorang yang pertama kali adalah adalah bahasa lisan. Bahasa lisan adalah bahasa yang utama dan pertama yang dikuasai seseorang. Kemampuan bahasa lisan seseorang dapat dilihat dengan mudah dari kemahiran mereka berbicara. Oleh karena itu, mahasiswa asing yang belajar BIPA, mereka ingin segera dapat berbicara dalam bahasa Indonesia.

Belajar bahasa pada hakikatnya adalah belajar budaya. Mahasiswa asing yang belajar BIPA pada hakikatnya mereka belajar budaya Indonesia. Bahasa Indonesia dan budaya Indonesia tidak dapat dipisahkan dalam pengembangan bahan ajar BIPA. Oleh karena itu, dalam bahan ajar BIPA tingkat pemula juga terkandung materi budaya Indonesia. Hal ini selaras dengan pendapat Pangesti \& Wurianto, (2018) yang menyatakan dalam mengembangkan bahan ajar BIPA untuk tingkat pemula perlu memasukkan budaya Indonesia. Budaya Indonesia yang diintegrasikan dalam bahan ajar BIPA pemula, berupa budaya lokal, seperti yang dilakukan oleh Suher (2017) dan budaya nasional oleh Tupan (2019) yang mengembangkan bahan ajar BIPA yang bermuatan budaya Indonesia.

Berdasarkan proses pengamatan terhadap beberapa bahan ajar BIPA tingkat pemula dan membaca sejumlah penelitian terdahulu dilakukan teknik tiru (T) dan modifikasi (M). Hasil teknik tiru diwujudkan dalam struktur tiap unit pelajaran yang terdiri atas 1) topik pelajaran, 2) tujuan, 3) uraian materi, 4) latihan, 5) catatan tata bahasa, dan 6) daftar kata baru atau kata sulit. Hasil modifikasi dalam bahan ajar BIPA yang dikembangkan adalah disesuaikannya bahan ajar hasil pengembangan ini untuk pembelajaran daring. Bahan ajar BIPA daring adalah sesuatu yang baru dalam khasanah pengembangan bahan ajar BIPA. Selain itu, bentuk modifikasi berupa kamus mini di bagian akhir tiap unit. Kamus mini tersebut berisi daftar kosakata target yang diberi padanan dalam bahasa Inggris dan disediakannya tempat kosong dalam kamus mini tersebut untuk diisi padanan dalam bahasa pertama pebelajar BIPA. Pemberian tempat kosong untuk diisi padanan kata dalam bahasa pertama pebelajar BIPA dimaksudkan untuk membantu para pebelajar yang tidak menguasai bahasa Inggris.

\section{Kelayakan bahan ajar}

Berdasarkan uji kelayakan isi, bahasa, dan penyajian bahan ajar diperoleh hasil sebagai berikut.

Uji kelayakan bahan ajar BIPA dari aspek isi didasarkan pada isian angket yang diberikan kepada partisipan, yaitu para pebelajar asing yang menggunakan hasil produk pengembangan ini. Dari 73 partisipan, terdapat 57 partisipan yang mengisi angket atau sebesar $78 \%$ dari keseluruhan partisipan. Persentase $78 \%$ dianggap bisa mewakili partisipan. Dari alternatif jawaban di angket diketahui bahwa jawaban 1 (skor 4) dipilih sebanyak 474 kali, jawaban 2 (skor 3) dipilih sebanyak 285 kali, jawaban 2 (skor 2) dipilih sebanyak 144 kali oleh partisipan, dan jawaban 4 (skor 1) tidak ada yang memilih. Dengan demikian jumlah skor isian angket adalah $=\mathbf{f}$

$$
\begin{aligned}
& \mathbf{f}=(4 \times 474)+(3 \times 285)+(2 \times 144)=1.896+855+288=3.039 \\
& \mathbf{n}=\text { Jumlah skor maksimal }=(4 \times 15) \times 57=3.420 \\
& \mathrm{P}=\frac{f}{n} \times 100 \%, \mathrm{P}=\frac{3.039}{3.420} \times 100 \%=\mathbf{8 9 \%}
\end{aligned}
$$


Jika dilihat pada tabel 4, persentase sebesar $89 \%$ memiliki makna bahwa dari aspek isi, bahan ajar BIPA daring untuk pebelajar tingkat pemula termasuk kriteria sangat layak.

Uji kelayakan bahan ajar BIPA dari aspek bahasa dan penyajian didasarkan pada isian angket yang diberikan kepada partisipan, yaitu pakar BIPA dan dosen BIPA. Pakar BIPA yang membantu penelitian ini adalah Ibu Dra. Peni Dyah Anggari, M.Pd. Beliau telah berpengalaman mengajar BIPA di Amerika dan Indonesia lebih dari 20 tahun. Dosen BIPA yang berpartisipasi mengisi angket antara lain Nissa Rahma Nur Aprilian, M.Pd., M.A, Nanang Syaiful Rohman, M.A, dan Vania Maherani, S.Pd. Dari aspek bahasa diketahui bahwa jawaban 1 (skor 4) dipilih sebanyak 14 kali, jawaban 2 (skor 3) dipilih sebanyak 10 kali, jawaban 2 (skor 2) dipilih sebanyak 1 kali oleh partisipan, dan jawaban 4 (skor 1) tidak ada yang memilih. Dengan demikian jumlah skor isian angket adalah $=\mathbf{f}$

$$
\begin{aligned}
& \mathbf{f}=(4 \times 14)+(3 \times 10)+(2 \times 1)=56+30+2=88 \\
& \mathbf{n}=\text { Jumlah skor maksimal }=(4 \times 5) \times 5=100 \\
& \mathrm{P}=\frac{f}{n} \times 100 \%, \mathrm{P}=\frac{88}{100} \times 100 \%=\mathbf{8 8 \%}
\end{aligned}
$$

Berdasarkan tabel 4, persentase sebesar $88 \%$ dapat ditafsirkan bahwa dari aspek bahasa, bahan ajar BIPA daring untuk pebelajar tingkat pemula termasuk kriteria sangat layak.

Dari aspek penyajian diketahui bahwa jawaban 1 (skor 4) dipilih sebanyak 13 kali, jawaban 2 (skor 3) dipilih sebanyak 9 kali, jawaban 2 (skor 2) dipilih sebanyak 3 kali oleh partisipan, dan jawaban 4 (skor 1) tidak ada yang memilih. Dengan demikian jumlah skor isian angket adalah $=\mathbf{f}$

$$
\begin{aligned}
& \mathbf{f}=(4 \times 13)+(3 \times 9)+(2 \times 3)=52+27+6=85 \\
& \mathbf{n}=\text { Jumlah skor maksimal }=(4 \times 5) \times 5=100 \\
& \mathrm{P}=\frac{f}{n} \times 100 \%, \mathrm{P}=\frac{85}{100} \times 100 \%=\mathbf{8 5 \%}
\end{aligned}
$$

Menurut tabel 4, persentase sebesar $85 \%$ dapat dimaknai bahwa dari aspek penyajian, bahan ajar BIPA daring untuk pebelajar tingkat pemula termasuk kriteria sangat layak.

\section{PENUTUP}

Penelitian pengembangan bahan ajar BIPA daring untuk pebelajar tingkat pemula rendah berhasil diwujudkan dan diseminasi kepada masyarakat luas secara online. Bahan ajar ini terdiri atas tiga belas unit pelajaran. Tiap unit pelajaran dikembangkan bertumpu pada topik aktual. Topik-topik aktual tersebut tentang berkenalan, kampus, rumah, kantor, kantin, taman, dan pasar. Ragam bahasa Indonesia yang digunakan dalam bahan ajar ini ragam komunikatif. Selain itu, bahan ajar ini difasilitasi bahasa bantu bahasa Inggris. Berdasarkan uji kelayakan terhadap aspek isi, bahasa, dan struktur penyajian dapat disimpulkan bahwa bahan ajar BIPA daring ini sangat layak digunakan oleh pebelajar tingkat pemula rendah. Dalam bahan ajar BIPA daring untuk pebelajar tingkat pemula ini belum dieksplorasi bacaan sebagai bagian dari sajian bahan ajar. Oleh karena itu, pengembang bahan ajar BIPA daring selanjutnya disarankan untuk memasukkan bacaan yang sesuai dengan karakteristik pebelajar tingkat pemula rendah. Selain itu, dalam melaksanakan pembelajaran daring, dosen disarankan untuk mampu mengadaptasi bahan ajar ini sesuai dengan moda pembelajaran virtual yang dikuasai oleh pebelajar.

\section{DAFTAR PUSTAKA}

Arumdyahsari, S., Hs, W., \& Susanto, G. (2017). Pengembangan Bahan Ajar Keterampilan Berbicara Bahasa Indonesia. Jurnal Pendidikan Bahasa Dan Sastra Indonesia, 1(3), 326-337. https://doi.org/10.22219/KEMBARA.Vol3.No1.98-106 
Astuti, W., \& Bewe, N. (2020). Listening Learning of Indonesian for Speakers of Other Languages (BIPA) for Academic Purposes. Journal of Education, Teaching, and Learning, 5(2), 401-408. https://doi.org/10.26737/jetl.v5i2.1985

Budiana, N. B., Indrowaty, S. A., \& Ambarastuti, R. D. (2018). Pengembangan Buku Teks BIPA Berbasis Multikulturalisme bagi Penutur Asing Tingkat Pemula. Diglossia: Jurnal Kajian Ilmiah Kebahasaan Dan Kesusastraan, 9(2), 108. https://doi.org/10.26594/diglossia.v9i2.1141

Canale, M., \& Swain, M. (1980). Theoretical bases of communicative approaches to second language teaching and testing. Applied Linguistics, 1(1), 1-47. https://doi.org/10.1093/applin/I.1.1

Choudhury, S., \& Pattnaik, S. (2020). Emerging themes in e-learning: A review from the stakeholders' $\begin{array}{lllll}\text { perspective. Computers aducation, } 103657 . & \end{array}$ https://doi.org/10.1016/j.compedu.2019.103657

Corbera, E., Anguelovski, I., Honey-Rosés, J., \& Ruiz-Mallén, I. (2020). Academia in the Time of COVID-19: Towards an Ethics of Care. Planning Theory and Practice, 21(2), 191-199. https://doi.org/10.1080/14649357.2020.1757891

Ellis, R. (1995). The Study of Second Language Acquisition. Oxford University Press.

Fariqoh, R. (2016). Pengembangan Bahan Ajar Membaca untuk Pembelajar Bahasa Indonesia Penutur Asing Tingkat Dasar. Riksa Bahasa, 2(2), 219-223.

Fatahillah, A. (2020). Pengembangan Bahan Ajar BIPA Tingkat Pemula (Beginner) di Songserm Wittaya Mulnithi Kuthao Hadyai Thailand. Jurnal Penelitian, Pendidikan, dan Pembelajaran, 15(32).

G Gall, M. D., Gall, J. P., \& Borg, W. R. (2007). Educational research: An introduction (8. Utg.). AE Burvikovs, Red.). Pearson.

Hermanto, H. (2019). Pengembangan Bahan Ajar Berbicara Bahasa Indonesia Bagi Penutur Asing Tingkat Pemula Tinggi. Dinamika: Jurnal Ilmiah Ilmu Hukum, 25(15). http://riset.unisma.ac.id/index.php/jdh/article/view/4618

Indonesia, K. B. B. (2008). Departemen Pendidikan Nasional. Pusat Bahasa.

Lina Tiawati, Refa. (2018). Indonesian Language Learning Planning for Foreigners (BIPA) for Beginners Level (Perencanaan Pembelajaran Bahasa Indonesia Bagi Penutur Asing (BIPA) Untuk Tingkat Pemula). Gramatika STKIP PGRI Sumatera Barat, 4(2). https://doi.org/10.22202/jg.2018.v4i2.2732

Little, D. (2006). The Common European Framework of Reference for Languages: Content, purpose, origin, reception and impact. Language Teaching, 39(3), 167-190. https://doi.org/10.1017/S0261444806003557

Mbulu, J., \& Suhartono. (2004). Pengembangan Bahan Ajar. Elang Mas.

Moorhouse, B. L. (2020). Adaptations to a face-to-face initial teacher education course 'forced' online due to the COVID-19 pandemic. Journal of Education for Teaching, 609-611. https://doi.org/10.1080/02607476.2020.1755205

Morgan, H. (2020). Best Practices for Implementing Remote Learning during a Pandemic. The Clearing House: A Journal of Educational Strategies, Issues and Ideas, 93(3), 135-141. https://doi.org/10.1080/00098655.2020.1751480

Muliastuti, L., \& Camila, R. (2016). Sahabatku Indonesia A1. Badan Bahasa Kemendikbud.

Murphy, M. P. A. (2020). COVID-19 and Emergency eLearning: Consequences of the securitization of higher education for post-pandemic pedagogy. Contemporary Security Policy, 41(3), 492-505. https://doi.org/10.1080/13523260.2020.1761749

Murtianis, Andayani, \& Rohmadi, M. (2019). Text Book As a Java Culture Recognition Media in Indonesian Learning For Foreign Speaker (BIPA) in Sebelas Maret University. International Journal of Educational Research Review, 427-434. https://doi.org/10.24331/ijere.573944

Ningsih, S. (2020). Persepsi Mahasiswa Terhadap Pembelajaran Daring Pada Masa Pandemi Covid-19. JINOTEP (Jurnal Inovasi Dan Teknologi Pembelajaran): Kajian Dan Riset Dalam Teknologi Pembelajaran, 7(2), 124-132. https://doi.org/10.17977/um031v7i22020p124

Nuraeni, E. (2016). Pengembangan Bahan Ajar Membaca Bahasa Indonesia bagi Penutur Asing (BIPA) Berbasis Budaya Indonesia Tingkat Menengah di Indonesian Studies Program (ISP) MCE. Nosi, 4(2), 90-101.

Nurlina, L. (2017). Indonesian Speaking Learning Material Development Based on Central Java 
Cultural Values for Foreign Students. 109(Aecon), 160-163. https://doi.org/10.2991/aecon17.2017 .29

Nurlina, L., Andayani, Winarni, R., \& Slamet, S. Y. (2017). Kebutuhan Pengembangan Bahan Ajar Menyimak Bermuatan Budaya Lokal Jawa Tengah untuk Pembelajaran BIPA. The 1st International Conference on Language, Literature and Teaching, 734-738.

Nurlina, L., \& Israhayu, E. S. (2014). BIPA Learning Material Development for Empowering Thailand Students' Writing Competence. Educare, 7(1), 57-66.

Pangesti, F., \& Wurianto, A. B. (2018). Pengembangan Bahan Ajar BIPA Berbasis Lintas Budaya Melalui Pendekatan Kontekstualkomunikatif. Jurnal Pendidikan Bahasa, 7(2), 342. https://doi.org/10.31571/bahasa.v7i2.1015

Pranandari, N. (2013). Pengembangan Bahan Ajar Berbicara Bahasa Indonesia bagi Penutur Asing Tingkat Pemula tinggi. Journal of Chemical Information and Modeling, 7(2).

Oztok, M., Zingaro, D., Brett, C., \& Hewitt, J. (2013). Exploring asynchronous and synchronous tool use in online courses. Computers \& Education, 60(1), 87-94. https://doi.org/10.1016/j.compedu.2012.08.007

Rafferty, E., Barnard, E., \& Suharni, L. (2014). Let's Speak Indonesian: Ayo Berbahasa Indonesia. NUS Press., Volume 2.

Ramadhani, R., Hs, W., \& Harsiati, T. (2016). Pengembangan Bahan Ajar Keterampilan Berbicara Bahasa Indonesia bagi Penutur Asing Tingkat Pemula. Jurnal Pendidikan - Teori, Penelitian, Dan Pengembangan, 1(3), 326-337.

Saddhono, K., Ridwan, M., Suherman, A., Anwar, K., \& Putri, N. Q. H. (2020). The Development of Interactive E-book of Teaching Indonesian for Speaker of Other Language (TISOL) Containing Local Wisdom with Scientific-Thematic Approach. Journal of Physics: Conference Series, 1573(1). https://doi.org/10.1088/1742-6596/1573/1/012002

Sari, R., \& Cahyani, D. D. (2020). Pengembangan Buku Ajar BIPA Untuk Tingkat Pemula Berbasis Kebutuhan Pemelajar. Indonesian Journal of Education and Learning, 4(1), 448-455. https://doi.org/10.31002/ijel.v4i1.3398

Seels, B., \& Richey, R. (1994). Instructional Technology: The Definition and Domains of The Field. AECT.

Siroj, M. B. (2018). The Development of Integrative Model for Indonesian Language Teaching Materials in ICT Based Socio Culture Studies for Intermediate non Native Speakers. International Journal of Linguistics, Literature and Translation, 1(3).

Sriwulandari, Y. A., \& Ramadhani, A. A. (2018). Pengembangan Bahan Ajar BIPA Darmasiswa IKIP Budi Utomo Malang. Jurnal Ilmiah Ilmu Pendidikan, 1(3), 90-93.

Sudana, P. A. P., Paramarta, I. M. S., Paragae, I. P. N. S., \& Utama, I. D. G. B. (2019). Developing Balinese Culture-Based Textbook for Intermediate Level BIPA Instruction. Advances in Social Science, Education and Humanities Research, 394, 74-80. https://doi.org/10.2991/assehr.k.200115.013

Suher, R. P. H. (2017). Pengembangan Materi Ajar BIPA Melalui Budaya Lokal Jawa Timur. Elementary School Education Journal), 1(1), 48-56.

Suprihatin, A. (2015). Pengembangan Bahan Ajar Membaca Program Bahasa Indonesia bagi Penutur Asing Tingkat Intermediate. Nosi, 3(3), 297-306. http://www.pbindoppsunisma.com/wpcontent/uploads/2015/09/1.-Agnes-Suprihatin-297-306.pdf

Susanto, G., Anggari, P., Ramadhani, R. P., \& Nisrina, D. (2020). Bahan Ajar BIPA Tingkat Dasar 1. MNC Publishing.

Susanto, G. (2008). Bahan Ajar BIPA Tingkat Pemula untuk Pebelajar Jepang. Tesis tidak diterbitkan. Malang: UPPS UM.

Susanto, Gatut. (2015). Prinsip Dan Teknik Mengajarkan Kosakata BI Kepada Pebelajar BIPA. Diksi, 14(2), 179-186. https://doi.org/10.21831/diksi.v14i2.6599

Susanto, Gatut, Suparmi, S., \& Rahayu, E. Y. (2020). The Emotional Geography of International Students in Online Bahasa Indonesia Learning during the COVID-19 Pandemic Geografi Emosi Mahasiswa Internasional dalam Belajar Bahasa Indonesia secara Daring pada Masa COVID-19. Journal of International Students, 10(S3), 161-179.

Suyitno, I., Susanto, G., Kamal, M., \& Fawzi, A. (2019). The cultural and academic background of 
BIPA learners for developing Indonesian learning materials. Pertanika Journal of Social Sciences and Humanities, 27(T2), 173-186.

Tanwin, S., \& Rosliani, R. (2020). The Development of Indonesian Language Teaching Materials for Beginner Level of Foreign Speakers with Local Content. Budapest International Research and Critics in Linguistics and Education (BirLE) Journal, 3(3), 1600-1613. https://doi.org/10.33258/birle.v3i3.1250

Tolimson, B. (2014). Developing for Language Teaching. Bloomsbury.

Utami, D. A., \& Rahmawati, L. E. (2020). Pengembangan Bahan Ajar Berbasis Modul Interaktif bagi Pemelejar BIPA Tingkat A1. KREDO: Jurnal Ilmiah Bahasa Dan Sastra, 3(2), 277-294. https://doi.org/10.24176/kredo.v3i2.4747

Widodo, C., \& Jasmadi. (2008). Buku Panduan Menyusun Bahan Ajar. PT Elex Media Komputindo.

Widodo, H., Susanto, G., \& Woods-Hunt. (2011). Living Indonesian: Textbook BIPA for Beginning Level Intensive Indonesian Language Course. UM Press.

Yurensi, C. D., Damaianti, V. S., \& Idris, N. S. (2018). Pengembangan Bahan Ajar Kosakata untuk BIPA Anak Usia Dini dengan Pendekatan Integratif. 39-44. 